\title{
The Development of Nietzsche’s Aesthetics
}

\author{
LIN Danni \\ École Pratique des Hautes Études, Paris, France
}

\begin{abstract}
Aesthetics is an important part of F. Nietzsche's ideological system. This paper is based on Nietzsche’s experience and masterpieces of different periods, reviewing the changes of his aesthetic idea, in order to grasp the development of Nietzsche's Aesthetic theory, then we found that Nietzsche's Aesthetics has a close relationship with the life, practice and politics.
\end{abstract}

Keywords: Nietzsche, aesthetics, philosophy

In the Modern Western Philosophy, there is no doubt that Friedrich Wilhelm Nietzsche (1844-1900) is one of the most typical philosophers. His theory, as well as himself, is always very controversial so that he has been recognized not only as a genius, but also a crazy man. He ever came up with a famous idea, "revaluation of all the values”, but in fact, Nietzsche himself also became what was revaluated for many times, especially after the World War Two. He lived in the 19th century, but his value was not be properly recognized before he died; although his theory finally became famous, spread to all over the world in the 20th century, but unfortunately, was misused by Nazis. However, "Nietzsche was not as a scholar but as a living person to do his philosophic studies, he infused his philosophy with his own character” (Zhou, 1986, of Preface, p. 2). So, his point of view usually presented unique individual feature. In term of Aesthetics,

His main achievement of Aesthetics was not the discussion of academic theory, but to solve the fundamental problem of life. He advocated an aesthetic attitude to life-in fact, it was a kind of philosophy of life. He ever said that the traditional Aesthetics was just for the receiver, but he wanted to build up the Aesthetic of the giver-which meant the artist. (Zhou, 1986, preface)

Obviously, No matter how controversial it was, it could be an example of great value in the history of Aesthetic.

\section{In the Early Stage: The Foundation of His Theory}

When we refer to the early background of Nietzsche, we can see that the time in his youth was very special and contributed much to the forming and development of his theory.

At the very beginning, Nietzsche's ideology already presented a sense of tragedy. From his adolescence to when he began to write The Birth of Tragedy in 1871, his ideas didn't become a maturity theory, but he had prepared to open up his own way.

LIN Danni, Ph.D. student, École Pratique des Hautes Études, Paris, France. 
The one important influential resource was the experience in his upbringing. When he was a child, he was very weak and often became sick. This was one of the reasons that he formed a solitary and sensitive character. The life with frequent illness was usually afflictive and lonely, so he was silent and introvert, as well as preferred thinking rather than talking, but he made his talk exactly. "He did not learn to speak until he was two and a half, he did so then comparatively correctly” (Bond, 2006, p. 197). This was not necessary but it was really beneficial to be a philosopher. What's more, this kind of sensitive character made him observe everything much more carefully than others, then thought them meticulously in his own method to find out the nature of it, in this way, he could catch many beauties that were seldom paid attention to by others, which helped a lot in the early development of his Aesthetics.

Then, Nietzsche’s family environment also made a difference. Nietzsche was born in a small town of Lutzen, near Leipzig, in the Prussian Province of Saxony. His father and grandfather, even several generations of his ancestor were all Lutheran pastor, so he grew up in an atmosphere of religion, which gave him a chance to know about the religions. This experience as well as the religions idea of Lutheran that he learnt about also became the knowledge base of his altitude as an antichrist later. In 1849, when he was only five, his father died from a brain ailment. Before long, in the year of 1850, his younger brother also died. In fact, he grew up in a family donated by woman. A series of death happened on his close relatives let the young Nietzsche begin to consider about the serious problem of "life and death" much earlier and deeper than most of children at his age. In his biography about his youth, which was written by his sister, we could find some evidences. His sister remember that

I remember perfectly well the high opinion my brother now had of himself, for from that time forward he always laid stress upon his being much older than I was and used to call me "a little girl," although there was only two years' difference between us. I ought to point out that Fritz was a big and strong child, while I was small and delicate-a fact which would account for his always having been taken for much the elder. (Forster-Nietzsche, 1912, p. 130)

This proved that Nietzsche was more mature than his real age. After using his contemplative time to focus on thinking, he developed his thinking ability and gradually made his own judge of value in new standard.

Nietzsche's early reading experience was also an important influential resource, which was even much more directly and pointed out the destination for many of his ideas. As we all know, Nietzsche’s ideology in his early stage was strongly affected by Arthur Schopenhauer, whose theory once became the important foundation material of Nietzsche's idea at that time. When Nietzsche was in his twenties, he read The World as Will and Representation, "he had felt as though Schopenhauer had written expressly for him” (Bond, 2006, p. 197). Besides this, Nietzsche also liked the music of Wagner and appreciated this great musician.

\section{Apollonian and Dionysian: The Birth of Tragedy}

Generally speaking, The Birth of Tragedy was regarded as a maiden work of Nietzsche. It was also the birthplace of his Philosophy and Aesthetics. In this book, Nietzsche borrowed the symbols of Apollo and Dionysus from the Greek Mythology. Through them, he tried to explain the original of art, as well as the essential and function of art. The preface of it was an article that he wrote to Wagner, it could be inferred that Wagner and his music spirit ever had an indispensable influence in Nietzsche.

The first thing was to use these two adjectives, which were called as “Apollonian” and "Dionysian”, to set up two symbols and have a comparison. “Apollonian” in this book stood for cool, distance, ration and lawgiver. 
The art of it was plastic art, "Freeze at a moment”. In the image of Apollo, he possessed "a discreet limitation, a freedom from all extravagant urges, the sapient tranquility” (Nietzsche, 1956, p. 21). Its complete, coherent visions implied order and a kind of self-control, which was called "Apollonian norm”. Apollo was the interpreter of dreams, taking deep delight in the contemplation of his dream. In contrary, "Dionysian" in this book stood for ecstasy, intoxication, mystery and disorder. The art of it was music, which was a non-visual form without appeal to image. Totally different from Apollonian, Dionysian was exuberance and ecstasy, the chorus and the joy of it was "so stirred, the individual forgets himself completely" (Nietzsche, 1956, p. 22). When it came to the power of Dionysian, Nietzsche said "Not only does the bond between man and man come to be forged once more by the magic of the Dionysian rite, but nature itself, long alienated or subjugated, rises again to celebrate the reconciliation with her prodigal son, man” (Nietzsche, 1956, p. 37). This was because Nietzsche regarded Dionysian power as "a supernatural power" and thought highly of it. "If however the figures of Apollo and Dionysus are now comprehended in terms of the wide symbolic significance given to them by Nietzsche it is important to connect this notion of the key role of the symbol back to Kant’s discussion” (Banham, 2006, p. 5).

Between Apollonian and Dionysian, Nietzsche did his brilliant exposition and particularly stressed on their relationship. He thought that in the two immediate creative conditions of nature, which were "the imagery of dreams" and "the ecstatic reality", "every artist must appear as 'imitator”, besides the Apollonian dream artist and the Dionysian ecstatic artist, artists could also be "dream and ecstatic artist in one" finally, as in Greek tragedy.

Nietzsche was familiar with tragedy and used the art of tragedy to analyze the world and the life. He thought pleasant sensation of the tragedy comes from Dionysus' wisdom, which originates from music spirit. Function of tragedy is to give life a metaphysical comfort. ${ }^{1}$ This attitude demonstrated that he excelled Schopenhauer's Pessimistic Philosophy of Life and emphasized the Dionysian impulse. In his opinion, people should not stay in the metaphysical presentation which called plastic, but to be full of life force, changing from pessimistic power to creative power, which was the true meaning of Dionysian spirit and the real Aesthetic which was closely related to our lives. It can be regarded as a clue to the fact that Nietzsche's Aesthetics was born with disorder and impulse; naturally, it was a contra of tradition. Even he began to work in college as a scholar later time, the attitude was still the same as it.

In the end of The Birth of Tragedy, Nietzsche shouted that "Blessed people of Hellas!”, expressed that his will save the German spirit, to express the tragic myth and be back into an ancient Greek existence.

\section{A Sharp Turn and Later Stage}

About the middle of his thirties, Nietzsche experienced a sharp turn in his ideas and theory. He broke up with Richard Wagner, whom he once appreciated much and kept close relationship with.

What was worth mentioning was that after breaking up with Wagner, Nietzsche still acknowledged that he was very similar to Wager in their ties of blood. Obviously, Nietzsche made a further step in his self-criticism. He was so disordered and sensitive, but intensely criticized disorder and sensitivity; he was romantic and pessimistic, but intensely criticized the romantic and pessimism.

${ }^{1}$ The reference is The Birth of Tragedy. 
What is the first and last thing that a philosopher demands of himself? To overcome his age in himself, to become 'timeless'. With what then does the philosopher have the greatest fight? With all that in him which makes him the child of his time. Very well then! I am just as much a child of my age as Wagner—I'm a decadent. (Ludovici, 1911, preface)

Making a comprehensive survey of Nietzsche's Aesthetics, we can find that he regarded Dionysian ecstatic was the psychological premise of all behaviors related to appreciation of beauty. It was the Aesthetic foundation of ecstatic status. However, the nature of Dionysian ecstatic was the excess of power and the feeling of strong power. Therefore power is the necessary qualification of beauty. He even thought that when a artist created things, "he rejoices as an artist, he enjoys himself as power, he enjoys the lie as his form of power" (WP853, Nietzsche, 1967, p. 452). At that time, his Aesthetic system was sustained by the will to power.

In his later stage, when his Aesthetic system had been built, his answer to the Aesthetic also developed much further. From the plastic art like the beauty of Apollonian to the life force like the beauty of Dionysus, his standpoint became more close to the human being and their lives. He thought unrestrained beauty was just nonsense. In the final analysis, people devoted themselves to other things. However, in the meantime, they regarded all the things that reflected their images as beauties. The Aesthetic judgment of beauty was a kind of vanity, so we could say that people made the world more humane. ${ }^{2}$ He also emphasized the desire of human, in Nietzsche contra Wagner, Nietzsche definitely said that Aesthetic was not other things but "applied physiology". He focused on body and spirit. In his masterpieces of later stage, for example, he said the body's vigor was the motive power of the Art, our ability of appreciating the beauties depended on the vigor of our bodies. In this vigor, the power of libido was the most important part. The value of Aesthetics depended on the value in biology field. The genuine genius was equal to the lunatic.

Nietzsche became seriously insane and went totally mad after he finished his last masterpiece, Dionysus Ode. This ode was a symbol of his intoxicated, also a strong expression of his long-term active Dionysian Aesthetics. Finally, his own life went on the same way with his theory as well.

\section{The Affection and the Use of Nietzsche's Aesthetic Theory}

After the death of Nietzsche, his theory was misused during the World War One and the World War Two. In that period, Nietzsche and his theory was very popular. It was said that during the World War One, many German soldiers carried two books, one was Bible, the other was Thus spake Zarathustra. As we all know, the theory about strong power also had an influence on Hitler, one of Nietzsche's motto was obeyed by Hitler for all his life. “The Nazi's use of Nietzsche caused(and continues to cause) an upheaval from the moment National Socialism arose.In the 40s,persons such as Kaufmann,Bataille,Jaspers,Camus,and the Mann brothers, fought to proctect Nietzsche’s writings from Nazi perversions, while others such as McGovern,Lukacs,and Brinton held that the Nazis were justified in using certain elements of Nietzsche’s philosophy” (Santaniello, 1994, p. 149). What was inconceivable, Nietzsche became a spirit symbol of Nazis, although what Nietzsche really wanted to express was not the question of cruel war. In Nietzsche's masterpieces, from The Birth of Tragedy in his early stage to the works in his later stage, he always kept paying attention to the political problems, although sometimes he didn't express it directly even just hide it in the discussion of Ancient Greek or something about myth and God. However, this kind of attention was not meant that it could be used as a political tool. It could not be regarded as

\footnotetext{
2 This refers to The Dusk of the Moral Idol, 19-20.
} 
a drastic political method.

As for Philosophy, Nietzsche was also a begging of a modern revolt. There were some famous examples, such as Martin Heidegger's Original Ethics that was based on analysis about living state, Jean-Paul Sartre's explanation to the meaning that human lives, and so on. Though it did not appear as a typical form of Aesthetics, Nietzsche's style of revolt and self-criticism is the Aesthetic spirit. It offered a structure of Aesthetics and a standard to judge the beauty, which was popular among later philosophers and became one of the most popular theories for a long time. Nietzsche's idea was also under the influence of Kant, but it was different from Kant's.

Kantian symbols operate through the double function of judgment's relation to a rule, a universality of application and conceptuality, Nietzsche's symbols by contrast operate by means of immersion in images forming an rule-governed process whereby both oneself and any perceptual states in question are translated into a medium of vision which represents the states in question to oneself. (Banham, 2006, p. 6)

Last but not least, Nietzsche’s Aesthetics also has special meaning toward reality. First, he acknowledged the nature of life was tragedy, but he did not approve pessimism. He hated perfect, regarded the integration of the true, the good and the beautiful was "the fourth religion", he directly faced the reality far from perfect, recognized the tragic nature of life clearly and correctly, at the same time, he explored life further than Schopenhauer's cognition of Pessimistic Philosophy of Life, so he was not pessimism but held an extremely optimism attitude. Nietzsche used his strong life force and "the will to power" to enjoy the tremendous beauty of tragedy, which has an obvious humanism. This theory was beneficial to guide people to live their lives optimistically and think highly of lives, face their suffering bravely, even hold an aesthetic attitude to treat the death, which was really a theory of great value.

Certainly, Nietzsche also had some problems, which can’t be solved by him. For example, he thought that the God was dead; we trapped in a crisis of what could be believed because we didn't have a God any more, but he hadn't come up with a properly new target for us to believe in. He destroyed the old tradition, but still did not finish the task of establishing a new system. In Aesthetics, he also changed the key point of Aesthetics from academic theory to the real life, which was closely related to every person. In his Aesthetic system, sorrow and death were not so terrible, they are even a way to achieve splendid glory. We can appreciate it as for an art of behavior, even can admire it as a holy thing. In this way, when people suffer from the deep pain or agony - in fact, this is the kind of suffer that anyone was suffered from anytime in a sense- -they will probably not sink into the pessimism and never stand up on their own feet to overcome all barriers, instead, their will enjoy their life whatever how hard it could be and regard themselves as a powerful uncommon "superman" with great joy. This was a combination of power and beauty, and a high position form of Aesthetic.

In a word, although Nietzsche's Aesthetics was just a part of his whole philosophy system, it really has its unique value so that can't be taken place forever. Its feature began to form at the early stage of his life: sensitive and humane, and then this foundation was developed into a more mature stage, which was active and optimistic, expressing through the concept he borrowed and enriched: Dionysian. After that, his Aesthetics attitude appeared a turn accompanied with the sharp turn happened in his whole theory system, which included more ingredients of self-criticism than before, but the appreciation of Dionysian ecstatic didn't change, he still wanted to save the German spirit, to express the tragic myth, and be back into an ancient Greek existence. At last, his Aesthetic system was built up; he threw himself into it and went mad, leaving an important influence, as well as 
controversial problems remained to be solved.

\section{References}

Bond, S. (2006). Beyond good and evil (15): Nietzsche’s critique of Schopenhauer’s “vicious circle”. Minerva—An Internet Journal of Philosophy, 10, 197.

Banham, G. (2006). Art and symbol in Nietzsche’s aesthetics. Paper of Manchester Metropolitan University.

Forster-Nietzsche, F. (1912). The young Nietzsche. (A. M. Ludovici, Trans.). New York: Sturgis and Walton.

Hollinrake, R. (1982). Nietzsche and Wagner and the philosophy of pessimism. London: Allen \& Unwin.

Ludovici, A. M. (Tans.). (1911). The case of Wagner. New York: The Macmillan Company. (in English)

Nietzsche, F. (1956). The birth of tragedy (F. Golffing, Trans.). Garden City, New York: Doubleday Anchor Books.

Nietzsche, F. (1967). The will to power (W. Kaufmann and R. J. Hollingdale, Trans.). New York: Random House.

Santaniello, W. (1994). Nietzsche, God , and the Jews: his critique of Judeo-Christianity in relation to the Nazi myth. Albany: State University of New York Press.

Zhou, G. P. (1986a). Nietzsche: At the century's turning point. Shanghai: Shanghai People’s Publishing House. (in Chinese)

Zhou, G. P. (Tans.). (1986b). The birth of tragedy-The selections of Nietzsche's aesthetics. Shanghai: Joint Publishing. (in Chinese) 